\title{
On Heidegger on Education and Questioning
}

Babette Babich

Fordham University, babich@fordham.edu

Follow this and additional works at: https://fordham.bepress.com/phil_babich

Part of the Continental Philosophy Commons, and the Social and Philosophical Foundations of Education Commons

\section{Recommended Citation}

Babich, Babette, "On Heidegger on Education and Questioning" (2017). Articles and Chapters in Academic Book Collections. 75. https://fordham.bepress.com/phil_babich/75

This Article is brought to you for free and open access by the Philosophy at DigitalResearch@Fordham. It has been accepted for inclusion in Articles and Chapters in Academic Book Collections by an authorized administrator of DigitalResearch@Fordham. For more information, please contact considine@fordham.edu. 


\section{On Heidegger on Education and Questioning}

\author{
Babette Babich \\ Fordham University, New York, NY, USA
}

\section{Introduction}

Discussions of Heidegger and education take a number of perspectives as thematic foci. Questioning is key to Heidegger's thinking from the start of Being and Time, calling into question the foundations of what we suppose ourselves to know. Thus questioning involves a reflection on education, that is: both teaching and learning. Heidegger himself thematizes education, significantly so in the light of the political circumstances of his 1933 "Rectoral Discourse" as well as, in an inventive mode which would, as we shall see have been better had it been identified as such, as a reconstruction of his postwar reflections on the "Art of Teaching" and, most importantly, What is Called Thinking? Heidegger's reflections on questioning also include a meditation on both phenomenology and hermeneutics in "The Question Concerning Technology" in which he famously describes "questioning as the piety of thought."

\section{On Heidegger and Education}

A number of contributions to Heidegger and education may be found throughout discussions of Heidegger, not only on education and pedagogy but also in terms of Heidegger's specifically didactic style. [Consider, quite conspicuously, Peters (2009) as well as the contributions to Peters and Allen (2002), Ehrmantraut (2010) as well as Mayer (1960) as well as Meyer-Drawe (1988) and Nießeler (1995). On Eugen Fink's socialhermeneutic theory of education in particular, see Meyer-Wolters (1992)]. There are approaches to Heidegger and education that look specifically at Heidegger's reflections on technology drawing implications for newer forms of education, be it distance learning via and including computermediated/digital education, or else for today's interactive museum and science "learning centers" (Standish 1997; Waddington 2005). Still other considerations of Heidegger and education are concerned, some positively, some not so positively, with "authenticity." [See Nießeler (1995), once again, as well as Brook (2009)].

Many reflections on Heidegger and education begin with a reading of Heidegger's "Rectoral Address" [Heidegger (1985); the initial lecture was originally published as Die Selbstbehauptung der deutschen Universität Rede, gehalten bei der feierlichen Übernahme des Rektorats der Universität Freiburg $i$ Br. am 27. 5, 1933 (1933)], just where Heidegger specifically highlights the role of the university (à la John Henry 
Cardinal Newman or, indeed, à la Wittgenstein who also thematizes the university), and some go on to consider Heidegger's postwar reflections on the same National Socialist context, while other approaches review Heidegger's reflections after his return to university teaching in his 1951-1952 lecture course, What Is Called Thinking? inasmuch as Heidegger there too explicitly raises questions of education, specifically adverting to both teaching and to learning.

But Heidegger's concern with education is a broader one than may be indicated by wordsearch-specific remarks on education alone. Hence the attention Heidegger pays to learning as to learning to think and to questioning runs throughout his work, characterizing his style of philosophizing. Indeed, Heidegger's reflections on questioning in Being and Time mark a hermeneutically styled, phenomenological philosophy in general: hence its value for a specifically Heideggerian philosophy of education. [See Peters (2009), Gordon (1998), and Fink (1979) as well as his (1970) and overall Gallagher (1992)].

Heidegger's point of departure in Being and Time is classically instructive, highlighting the opposition between what we take ourselves to know, on the one hand, and what knowing ultimately is on the other. In this way, Heidegger's introductory quote from Plato's Sophist meditates on knowing unknowing: supposing oneself to know - "For manifestly you have long been aware of what you mean when you use the expression "being"" -which Heidegger conjoins with the unsettling disquiet of the recognition that one does not know, "We, however, who used to think we understood it, have now become perplexed" (Plato, Sophist (244a)).

This Platonic or Socratic reticence contra the presumed knowing that is characteristic of the sophist (by contrast with the philosopher in Plato in general) already offers an illustration of the revelation not of facts confidently assumed but attests to reflective breakdown. By contrast with presumed and long-standing knowledge ("you have long been aware of what you mean when you use the expression 'being"'), and precisely where one, that is singularized in the second person, plural in this case, anyone who, had not thought to question, questioning is prescribed as needful remedy for us, in the first person plural: "We, however, who used to think we understood it, have now become perplexed."

Heidegger's illustration of the breakdown of the ready to hand in the case of a tool like a hammer, defective or broken, or even simply missing, works as a halt, be it brief or longer lasting, in a given undertaking with which one has to do with the (now) problematic hammer. If we articulate an unspoken algorithm of problematization, the deficit calls the overall project as such into question. One can ask, must it be done? Now? What else might serve in place of a hammer? Where can a hammer be found? Such an array of reflections can in turn remand the project into an ad hoc stage, using work-arounds and substitutes - not only a hammer can be a hammer - or may initiate a stage of still further "preparation": anything worth hammering is best secured with the appropriate hammer for the job.

Philosophy itself is inherently of such a "workaround" character in some cases or else it is more classically of the preparatory and reflective variety. Undertaking to reflect on a given theme, we may ask ourselves what we know, and if we remember our Plato (as Whitehead once celebrated, we are all so many footnotes to Plato and as Ricoeur further emphasized, the goal of scholarship is ultimately to be a footnote), it often transpires not only that we do not know but much rather, as in the famous case of the son, Euthyphro, who, supposing himself to know what piety is, undertakes to bring his own father to court on the grounds of impiety, or else of Thrasymachus, who tells Socrates that he, Thrasymachus, knows justice to be no more than the interest of the commanding powers that be, and so on.

The Socratic (Nietzsche would correct us here and say the Platonic) lesson of knowing our own unknowing calls on us to reflect upon our longstanding and recalcitrant habit of presuming to know what we do not know.

Thus, again, we recall that Heidegger begins his Being and Time with the above-quoted citation from Plato's Sophist reflecting not on piety (like the Euthyphro) or justice (like the Republic) but 
precisely to raise the question of what we mean by being. By asking a classically Platonic question, Heidegger makes a phenomenological move, simultaneously hermeneutic, reflecting on the reflection and so bracketing the assumption with which he begins. We are to question whether we know what being is, but to this end, prior reflection is required.

Do we know what we are doing when we put something into question? What is questioning? What are we doing when we question?

This style of questioning is familiar to us as characteristic of Heideggerian philosophy. And just this questioning makes Heidegger essential reading for anyone reflecting on education, that is: on the nature of teaching and the nature of learning.

Heidegger routinely recalls us to such a starting point: as if philosophy were the proper project of the perpetual beginner. What, he asks us to ask, is the origin of the work of art? What is metaphysics? What is the relation of being and thinking, that is, the relation between what is and what is thought? What is the essence of, that is to say, what is the nature of, technology? How can we come to a free relation to it? What is the uncanniest of the uncanny? What is the danger? What is a thing? What is called thinking? Do we think? More subversively still, presuming the height of what we suppose human thinking to be to be science, does science itself think?

Here it must be noted that not all readings of Heidegger attend to the hermeneutic dimension proper to his phenomenology. Indeed a standing problem with traditional Anglophone readings of Heidegger and education, especially given the above-noted attentions to the Rektoratsrede, etc., corresponds to the analytic character of these readings (importantly, Thomson 2004, but see also Tubbs 2004 as well as many of the contributions to Peters and Allen (2002), a character compounded by the fact, shades of the abovenoted Euthyphro parallel (and we will return to this below), that such analytic approaches not only take themselves to be superior to other readings but also insist on describing themselves as "continental" and not, heaven forfend, as "analytic." The analytic tactic of refusing to be described as analytic works (not at all coincidentally) to resolve the analytic-continental divide on the side (as it were) of the angels: the AngloSaxon, the analytic, today the "dominant" side, proving its dominance by excluding other approaches altogether by denouncing them as "bad" or even mocking them. The institutional insularity of such a tactic (this is already a done deal) is less significant than the political dimensions of many readings today. For in reading Heidegger on education, it is traditional (and reasonable enough) to begin as already noted at the outset where Heidegger himself thematizes education, just as Michael Peters, likewise, has very insightfully shown [See Peters introduction to his co-edited collection 2002]. Yet to begin with Heidegger's address as a university administrator under the Nazi regime and to continue with Heidegger's postwar appeal to be permitted to continue to teach [Heidegger 2000; Hodge 2015 might have profitably drawn on some of the essays in Peters and Allen 2002] and to go on to reflect on his attention to teaching as such in the context of his return to the university in 1951-1952 [this is the point of departure for and organizing principle of Peters and Allen (2002), but for an insightful situating of this approach and including a useful bibliography including Michael Bonnet's contribution, see Peters' own chapter, "Introduction: Heidegger, Education, and Modernity," pp. 1-25] is to read Heidegger under the sign of Nazism and in the wake of the publication of the Black Notebooks that is also consequently under the sign of at least a certain anti-Semitism. [See not only my essay (Babich 2015a) which looks at education and the all-too-ontic instaurations of formation, inclusion and exclusion, but also the several contributions in English, including my own, to Malpas and Farin (2015)]. There are quite a few problems with this, none of which are served by a lack of hermeneutics or indeed a lack of an as yet unattempted Heidegger-specific philology. 


\section{When the Trivium Is No Longer Trivial: On Things that No Longer Go Without Saying}

From the outset, even with his earliest works, were this a discussion of history (rather than questioning), Heidegger reflects that what has transpired in the university is the displacement of pedagogy. This shift does not merely affect scholars and teachers - and this has been true for some time and is becoming ever more serious in a digital age but also in an age that focuses on the student as opposed to the teacher [consider Rançiere's wonderful return to Jacobin who taught that one need not be learned at all to teach at all (Rançiere 1991)], given current culture where the student but so too the ever and ever younger scholar, is valued with more grants, more initiatives, more support, more discussions/ thematizations by contrast with the increasingly devalued professor [including breaking professorial appointments into several junior positions, at other times more egregiously so as in the replacement of tenured appointments with adjunct or time-limited appointments, inevitably reducing qualification]. At the same time, Rançiere's celebratedly ignorant schoolmaster is increasingly more descriptive than prescriptive: newer "profs" routinely have never (quite) learned what it is they are supposedly engaged to teach. Some might argue that today's enthusiasm for digital humanities as for the flipped classroom or what we may call the wiki-teaching model betrays a confidence that sets adjuncts equal to tenured professors, only given that they might be, as they now are not, simply better paid: money makes the teacher and competence correlates to remuneration. Education works if and only if the result of education is employment.

These are contemporary concerns, as relevant for Ivan Illich as they were for Michael Oakeshott. For Heidegger, already and nearly a century ago, what is lost is the prerequisite "art" of teaching, that is: formation, or Bildung as such. Thus, Heidegger's concern is not the eons-old plaint of the older scholar vis-à-vis the young (as if this complaint were baseless, as it is not [Oakeshott is useful on reminding of this as is Illich and indeed
Nietzsche and many others all in addition to Heidegger. I highlight a discussion of Oakeshott in a discussion of the Harry Potter films, specifically Professor Severus Snape, Babich (2016)]). Ignoring both practical pressures, and without appealing to popular culture, as I have just done by referring to Alan Rickman's Snape, Heidegger refers to the supposedly classical components of the trivium, in his application to the rehabilitation committee that would have permitted him, as it ultimately did not permit him, to continue teaching after the war, i.e., grammar, dialectic, and rhetoric, are ordered, each of them, one to the other.

To quote Valerie Allen's and Ares D. Axiotis' reconstruction (less than clearly identified as a reconstruction, this essay is presented by the editor of the collection, Heidegger, Education, and Modernity, and on the publisher's website as a 'translation' of Heidegger's de-Nazification "deposition," here cited from Allen and Peters 2002 in the context of education, and by way of what I take to be an analogy to Plato's reconstruction of Socrates' 'defense'): Heidegger is here supposed to employ the conventionalities of traditional rhetoric. Thus we learn and are to learn:

\begin{abstract}
first from grammar which teaches us to speak aright, then to dialectic, which teaches us to reason aright, and finally to rhetoric, which teaches us to speak and reason well. Trivium, although a singular word, already points to the multiplicity within - tri-via$u m$, three roads made into one (Allen/Axiotis 2002, p. 32)
\end{abstract}

It is worth noting the ordinarily unadverted to classical dissonance: in a classical modality, one departs from convention by conventionally, formulaically, calling attention to this departure - the Jury may ignore the remarks of the witness - as Socrates famously does in his own Apology. In the face of a judicial hearing on Nazi guilt as a university professor, a hearing deciding whether Heidegger would or would not have the right to continue to teach, that is to say, to be "rehabilitated" after the war (the German text would highlight the play on Habilitation that is entailed), again, facing a committee empowered to decide whether to suspend his venia legendi or else to grant him the right to rejoin the members of the 
university teaching corps, Heidegger in just this circumstance is presented as spending his time talking about teaching.

That this would have been a dissonant thing to do is important to note. For, like Heidegger, every other professor subjected to this process [including, with the sole exception of Heidegger, every other Nazi rector in Freiburg (Babich 2015a)] had supported the Nazi regime and had taught under its auspices during the war. Almost all of the other affected rectors, administrators, and other academics comported themselves in their own denazification hearings by doing all the conventional things academics do: the very things Heidegger begins by listing as recommended to him (he was coached, as his colleagues were coached: all with good advice). [Again, I list those academics who succeeded Heidegger at Freiburg, all of whom were, successively, inevitably yet more involved with the Nazi regime than was he, and I note their fates after the war, fates which in most cases led to a straightforward continuation either in university governance or in research (Babich 2015a). Unlike his fellow Nazi academics, his co-professors, Heidegger conspicuously opted not to follow but to depart from protocol (the authors speaking in Heidegger's place use the word Scheideweg, a term used in 1955 by Dietrich von Hildebrand, to make Heidegger's choice plain). As Heidegger is here imagined as saying and this too follows the rhetorical tactic of the Apology: "I am admonished by earnest supporters to seize this occasion publically to recant any offending words and deeds and to promise to do the same in future lectures and publications" toward the end of a patent rehabilitation (Allen/Axiotis 2002, p. 29). This odd circumstance, and it has been noted that Plato's Socrates offers a parallel instantiation of this sort of fatally "rhetorical" display, has been detailed by my own teacher Hans-Georg Gadamer, not with too much sympathy in his: "Back from Syracuse" (Gadamer 1989).

Where Socrates undertook to "teach" the jury who would decide his life (and his death), so too Heidegger here is supposed as being minded to instruct his committee (a tone consistent with that adopted in the 1966 interview with Der Spiegel).
And like Socrates, that means expectedly (of course the results of the trial are known in each case), Heidegger was not successful. As Plato wrote the Apology (on Socrates' behalf and it is owing to this writerly reason that Nietzsche will speak of the pre-Platonic as opposed to the pre-Socratic philosophers), the description was largely ideal. Heidegger's enactment of a similar didacticism, written as if on his own account, is no exemplar for the aspiring academic.

Instructing his questioners on the "art of teaching," Heidegger is represented as detailing grammar and dialectic, using, that is to say, taking up the role of logic and of subjection (as he discussed this in two senses), including the risqué language that Allen and Axiotis opted to set into Heidegger's mouth (as if we might ever be allowed to forget that he was a farmer woman's son) belongs to the conception of the logos spermatikos [Heidegger is here depicted as speaking of "putting the mare beneath the stallion" (Allen/Axiotis 2002, p. 29) and so on) (Ibid., p. 35; for useful if approximately analytic and non-Heideggerian discussion of the logos spermatikos (a term that is not here employed although what Allen and Ariotis do insert into their essay surely glosses it), see Nye (1990)], and goes on to characterize rhetoric, the third in the series of the trivium, as "the bastard son of academe" (Allen/Axiotis 2002, p. 35).

The current Black Notebooks scandal brings this very "bastard son" into the light, not that we are all that happy to consider it, and a number of readers have urged that we banish it or at least bracket it (see for a discussion of these rhetorical recommendations: Babich 2015b). Still others, habitually antagonistic to Heidegger, like Emmanuel Faye and Richard Wolin, and to a lesser degree, those concerned to reduce the question of the meaning of Being to meaning as such, like Tom Sheehan, argue that it is less rhetoric as such than it is Heidegger who must be regarded as metaphorical bastard: Heidegger is to be jettisoned, stripped of any rightful claim to teach philosophy in the academy, let alone instruct us on education, much less philosophy of education. 


\section{Questioning}

Being and Time begins as a book in the way all monographs begin: we read a cover or title page and then a table of contents with a structural outline of themes. Detailed in the table of contents is a breakdown of the lineaments of the investigation, both promising and didactically useful to the reader.

An epigraph in Greek is featured on a single page, affixed as prefatory to the text, complete with an explanatory gloss. This is further augmented, if we are reading the English translation, with footnotes adverting to the translators' troubles with Heidegger's terminology:

For manifestly you have long been aware of what you mean when you use the expression 'being'. We, however, who used to think we understood it, have now become perplexed.

Heidegger glosses this in what is already his characteristic style as we know from the early writings: he updates the point in its current relevance and he intensifies it: "Do we in our time have an answer to the question of what we really mean by the word 'being'?" Elsewhere I describe this rhetorical style as cadence, letting fall; intensification, heightening or worsening a certain readerly anticipation; and retrieve, recovering or reprising an unadverted to meaning or philosophical advance (Babich 1993). Heidegger immediately answers his own cadence by intensifying its immediate purchase and persistence, do we have an answer? "Not at all." Heidegger thus goes on to vary and thus intensify Plato's own remark, "it is fitting that we should raise anew the question of the meaning of Being. But," Heidegger asks again, "are we nowadays even perplexed at our inability to understand the expression 'Being'? Not at all" (BT, [19/1]).

Heidegger thus begins Being and Time with a question posed to those of us, that would be philosophy in general, then and still today, who are persuaded that no question need be raised with regard to being. So regarded, Being and Time is nothing less than a questioning of a series of heretofore non-question-worthy questions regarding being. Instructive is Heidegger's way of approaching and hence of getting to articulate and thus to frame this kind of questioning.

We then read INTRODUCTION 1 followed on the next line by EXPOSITION OF THE QUESTION OF THE MEANING OF BEING and we move to the first section of the first part - I: THE NECESSITY, STRUCTURE, AND PRIORITY OF THE QUESTION OF BEING - all in majuscule in the English edition, where the first paragraph section is plain enough. The project to begin with declares " 1 . The Necessity of Explicitly Restating the Question of Being" necessary above all because "THIS question has today been forgotten" (BT I:1). Indeed, Heidegger goes on, the question is forgotten with a perfect good conscience. What is more, note the intensification, its oblivion is justified: there is no question; there is no need to question; there is, in fact, no kind of obscurity at all:

On the basis of the Greeks' initial contributions towards an Interpretation of Being, a dogma has been developed which not only declares the question about the meaning of Being to be superfluous, but sanctions its complete neglect (BT 1:1 [21/2])

Here, not unlike the accounts given by Glenn Most and John Hamilton detailing the ancient lyric poet, Pindar as not at all (not really) obscure (and so too or ditto Heraclitus), in today's very current university trend in a German context that is also to be named a "scientific" trend, "that which all ancient philosophers found continually disturbing as something obscure and hidden has taken on a clarity and self-evidence such that if anyone continues to ask about it he is charged with an error of method" (ibid.).

We hide the obscure in plain sight as obvious and ordinary, that is, as not worth asking about. But exactly this spells out what will be the project of Heidegger's undertaking:

By considering these prejudices, however, we have made plain not only that the question of Being lacks an answer, but that the question itself is obscure and without direction. So if it is to be revived, this means that we must first work out an adequate way of formulating it (BT 1:1 [24/4])

In this way, Heidegger proceeds in the next section to reflect on the need to illuminate and to 
clarify the "formal structure of the question of Being" (Cf. BT I:2).

There is a good deal to say about the prelude to this clarification just because, as it turns out, the prelude itself concerns our presuppositions or presumptions. This focus, of course, is the key to phenomenology. Contra these prior assumptions, contra the everyday knowledge one supposes oneself to have to begin with, just as Descartes begins his own Meditations by reflecting on things one takes oneself to know, we find our assumptions hinder the acquisition of founded knowledge. Husserl likewise deploys the same method: conscientiously setting aside, or bracketing, "prejudices" (as Heidegger and, later, as Gadamer will speak of them) for the sake of knowledge but also for the sake of any possible epistemology.

It is not ignorance, non-knowing, nescience that stands in the way of knowledge for philosophy. Thus Nietzsche ironically, provocatively emphasizes the origin of logic in illogic, that is, as he argues (the point is a critical one for Nietzsche) (Babich 2014), philosophers and educators alike assume the development of knowledge, or the constructive creation of knowledge, on the ground of learned ignorance.

We need to acknowledge our non-knowing, our ignorance. Where one already has knowledge, one does not undertake, just because one need not undertake, to seek knowledge. What one takes oneself to know stands in the way of learning as it also stands in the way of questioning as such. When we "already" know, when the answer is given, questioning can only be supererogatory: unneeded, or pointless.

Contra presumptive knowledge, convinced as we are by our "convictions," to use Nietzsche's term, Heidegger "formulates" nothing less obvious than the question of his project as a question. Thus Heidegger offers a preliminary hermeneutic phenomenology of what "belongs to any question whatsoever" (BT I:2), in order to make "the question of Being" manifest in "its own distinctive character" (ibid.).

Heidegger continues in this second section to articulate a phenomenology of questioning and because this phenomenology details a reflection on questioning, the phenomenological method is essentially hermeneutic:

Every inquiry is a seeking [Suchen]. Every seeking gets guided beforehand by what is sought. Inquiry is a cognizant seeking for an entity both with regard to the fact $t$ th $a t$ it is and with regard to its Being as it is (BT I:2)

Questioning is fundamentally intentional, most evidently when one reflects on questioning. For Heidegger, a "cognizant seeking" may be framed as an investigation: questioning "can take the form of 'investigating' ['Untersuchen'], in which one lays bare that which the question is about and ascertains its character" (BT I:2). In this sense, every questioning is also always (and already) a phenomenological reflection, directed to itself and raising a specifically hermeneutic question. This is what Heidegger calls, qua "inquiry about something," that express directedness to "that which is asked about [sein Gefragtes]" (BT I:2). And even here further reflection is significant because "all inquiry about something is somehow a questioning of something [Anfragen bei...]" (BT I:2).

In other words, one does not question in an arbitrary fashion but with intentional specificity concerning what is asked about, even when, especially when, the question is empty or proforma. In addition to what is thus thereby queried, an inquiry has that to which the questioning is directed: "that which is interrogated [ein Befragtes]" (BT I:2). Already "formal indication" is at work and Heidegger explains "specifically theoretical" questions of investigation, be they specifically philosophical or scientific, or, just for the instructive sake of an example, in terms of police work, as represented in popular crime fiction as "detective work". Here the example of the detective can be useful for understanding Heidegger's questioning in a way that lays bare both its pedagogic value in practice and its theoretical contribution to the philosophy of education.

It is already the specificity of questioning that "determines" and conceptualizes what is asked about. "Furthermore," Heidegger goes on to say, "in what is asked about there lies also that which is to be found out by the asking [das Erfragte]" 
(BT I:2). The question articulated already delimits as such or outlines the answer sought. HansGeorg Gadamer will emphasize this as the dialectical, dialogical character of hermeneutics. Here the example of the detective is appropriate as an investigation seeking "what is really intended" (ibid.). Once one finds this that is "really intended" in the case of a murder mystery, one has uncovered the intended "goal." One knows, in questioning suspects and eliminating possible alternatives, the answer to the mystery of the question of the "who" (who committed the murder?), and therewith, also, one knows, and this in advance, some part of the why question and some part of the how of it.

A hermeneutic phenomenology of questioning is useful in a further, more properly reflexive fashion. As Heidegger underlines, the investigator is not a neutrally objective subject or "immaculate perceiver" to use Nietzsche's language. Much rather: "Inquiry itself is the behaviour of a questioner, and therefore of an entity, and as such has its own character of Being" (BT I:2 [24/5]). Hence, if we keep to the murder mystery or detective instantiation of questioning, the literary (and in the interim also filmic and television) personage of Hercule Poirot goes about his inquiry differently than does (the variety of acteurly types exemplifying) Sherlock Holmes or else Agatha Christie's heroines, be it on the page or on the screen, and so too television's Peter Falk with his Socrates-like Detective Columbo by contrast, say, with Basil Rathbone's or Benedict Cumberbatch's Sherlock Holmes. Thus Heidegger, himself almost anticipating Falk's Columbo, easy given philosophy's paradigm investigator in the person of Socrates and his style of questioning, as we may recall this style in either the Euthyphro or the more educationally reflective Meno, reflects thematically that "When one makes an inquiry one may do so 'just casually' or one may formulate the question explicitly" (Ibid.). In either case, the fashion in which one frames the question as a particular questioner will make a difference.

What matters is both the logical framing that is the question and the very pre-given orientation toward what is sought that is also entailed in and by and through the question. This means that the question is indispensable in every way, and reflection on the question as such is not a merely formal reflection but exactly hermeneutico-phenomenologically essential: Here we pay attention in the following quote to the exigent character attributed to what must be:

Inquiry, as a kind of seeking, must be guided beforehand by what is sought. So the meaning of Being must already be available to us in some way (BT I:2 [25/5])

Heidegger, we recall, began by framing this point as not specific to the Being question as such but as holding generically for all questions, formally: "Every seeking gets guided beforehand by what is sought" (BT 1:2 [24/5]).

\section{Ask and It Shall be Given, Seek and Ye Shall Find}

It is the "Being question" which permits us to unpack the character of questioning:

\begin{abstract}
We do not know what 'Being' means. But even if we ask, "What is 'Being'?", we keep within an understanding of the 'is', though we are unable to fix conceptionally what that is' signifies. We do not even know the horizon in terms of which that meaning is to be grasped and fixed. But this vague average understanding of Being is still a Fact (BT I:2 $[25 / 6])$
\end{abstract}

In other words, the Being question, what is is, presupposes an understanding of what is is. That is, and this is also the logical question of reference, as of indication, as of signification, we need to know in some way (even prethetically as Heidegger will say) what we are talking about just in order to pose a question about it. And this is most particularly so in the case of the supposedly vague and general and for these reasons typically taken to be needless or pointless question of Being, just because the theme itself is being, i.e., is isness, what it is for something to be, that is, for it to be said of anything that it is. "What we seek when we inquire into Being is not something entirely unfamiliar, even if proximally, we cannot grasp it at all" (Ibid.).

The difference here with respect to Being is that we are not reflecting on the "origin" of a 
thing, whether in particular or in general. At issue then is not a question of genesis or genealogy, birth or mythology, i.e., "telling a story" to use Heidegger's language as he puts it, just to the extent that Being, of which we speak, Heidegger's Sein, and about which we seek to inquire, is not an entity or particular being and hence cannot be explicated as entities can be, that is, "by tracing them back in their origin to some other entities" (Ibid.). Rather as Heidegger explains:

Since Being is asked about, and since beings are constituted in their Being, all the conditions of questioning as articulated in this section turn out to be available. In so far as Being constitutes what is asked about, and "Being" means the Being of entities, then entities themselves turn out to be what is interrogated. These are, so to speak, questioned as regards their Being (BT 1:2 [26/6])

Paraphrasing Brentano on Aristotle, Heidegger reflects that "there are many things which we designate as 'being' ['seiend'], and we do so in various senses" (BT 1:2 [26/7]). Key to this overall involvement and to this very multiplicity, the questioning itself is also included as a reflection on Being, still more critically, as a reflection on the inquirer as well: we, ourselves, are as questioners to be implicated. Thus we are also to be put in question. This last point is decisive as the questioner turns out in this case to be quite singular, just given the inquirer's preoccupation both with him- or herself, reflexively and existentially, concerned, as Heidegger will explore this concern, with the very real and immediate question of its own being as such. Thus Heidegger logically locates Dasein in terms of questioning and with respect to the Being question as such:

to work out the question of Being adequately, we must make an entity - the inquirer - transparent in his own Being. The very asking of this question is an entity's mode of Being; and as such it gets its essential character from what is inquired about namely, Being. This entity which each of us is himself and which includes inquiring as one of the possibilities of its Being, we shall denote by the term "Dasein" (BT 1:2 [26/6])

If it is clear that this is as such specific to the kind of question that constitutes the so-called Being question, it ameliorates what can appear to be a kind of circularity. Heidegger thus pays attention to what he calls the "clue" of "the formal structure of the question as such," noting that "we made it clear that this question is a peculiar one, in that a series of fundamental considerations is required for working it out, not to mention for solving it" (BT 1:3 [28/8]).

Heidegger does not raise the question of questioning in order merely to frame the thematic of Being as such or even Dasein. Rather he is and remains concerned with exploring the notion of the question as such, as a question: noting that the "distinctive features" of the Being question as a question can only be illuminated fully once we "we have delimited it adequately with regard to its function, its aim, and its motives" (Ibid.).

Perhaps the most significant point then in Heidegger's sustained reflections in Being and Time and elsewhere is the difficulty of setting oneself on the path of actual inquiry. In other words, questioning as such, really questioning, turns out to be elusive. The problem, as Heidegger also writes in his What is Metaphysics?, coincides with authenticity, owning the question as one's own question and as such. That is the challenge of actually posing, framing, engaging, and putting the question as such, in other words: really questioning.

After reflecting on this challenge as his point of departure in What is Called Thinking?, Heidegger emphasizes that what is most thought-provoking of all is that we continue to fail to think: we are (still) not thinking. The point bears on the project of education. One can imagine Heidegger meant this statement to be heard in context, in this particular lecture course, as a vindication of his return to the university and in the wake of his failed efforts to impress the denazification committee that had instead withdrawn his venia legendi. For Heidegger, once restored to his university post, speaking to his students as they set out on what he tells them will be required of them in order to follow the path of those who mean to "learn to think" (Heidegger 1976), what must for Heidegger be underscored contrasts bridges, specifically, what must be presupposed to build and to use bridges, with what must similarly be presupposed for the sake of the leap. The metaphor is replete with references to the (very 
parodic) challenges of Nietzsche's Thus Spoke Zarathustra and Nietzsche's Übermensch (or overhuman). [I discuss this in a number of places; see most recently Babich (2013)]. For Heidegger, there can be no bridge and thus he underscores the necessity of the leap, to be distinguished from the "makeshift ties and asses' bridges by which humanity today would set up a comfortable commerce between thinking and the sciences" [Heidegger, What is Called Thinking?, p. 8].

With the example of the leap, Heidegger emphasizes that we can learn "only if we always unlearn at the same time" (Heidegger, What is Called Thinking?, p. 8). That same unlearning entails the need to let go. This is a kind of Gelassenheit - letting be or releasing what we think we know. [I explore some of the complexities of this notion using an aesthetic metaphoricity in Babich (2015c)]. The enemy of thinking, the enemy of learning, is nothing other than our original formation: what we have learned. Heidegger thus invites his listeners in his first lecture course given upon his return to teaching at the university to "radically unlearn what thinking has been traditionally" [Heidegger, What is Called Thinking?, p. 8]. And to that end, there is nothing but that same releasement that would "allow ourselves to become involved in questions that seek what no inventiveness can find" [Heidegger, What is Called Thinking?, p. 8].

Here Heidegger reflects - and just this is often quoted in essays on Heidegger and education - that "Teaching is even more difficult than learning" (Heidegger 1976, p. 15). The "even" in this articulation is to be foregrounded inasmuch as what is at issue in teaching is above all a letting learn. Just such a "solicitude" (as we remember the elusive because very compact discussion of solicitude [Fürsorge] in Being and Time) (Babich 2015d) is "difficult" precisely because "the real teacher lets nothing else be learned than - learning" (Heidegger 1976, p. 15). The teacher has to be more teachable than the one who learns, and at the same time, the teacher has to be able to allow the student to learn, whereby Heidegger offers his own version of Nietzsche's Zarathustran remonstration: one repays a teacher badly if one remains a student or a follower much less an acolyte, reflecting that the teacher has, just in order to be a teacher, to withdraw as such: like the pointer that Heidegger had already noted as part of the human condition of adverting to what is revealed as it obscures itself, as it withdraws. So too the teacher's comportment "often produces the impression that we properly learn nothing from him" (Heidegger 1976, p. 15). Said otherwise: a teacher to be a teacher must get out of the way. But what this means is not that the teacher is not important but that we do not know our teachers. As Nietzsche would say, we do not recognize them. This is ineluctable and it means that our true teachers, "true" as Nietzsche would say, are not honored with teaching awards: like Schopenhauer, as compared with Hegel or Wilhelm von Humboldt, they are not singled out as the great men and women of our educational institutions. Indeed, they are not likely to be known as such. The withdrawal in question for Heidegger, who prefers to speak of reticence, is not a matter of the initially noted focus on the student (as opposed to the professor), on the young (as opposed to the old). The teacher's withdrawal is not for the sake of support, that would be a kind of unsettling Fürsorge, that is a disrupting leaping-in for or on behalf of the other, no matter how well-intended the mentorship or how positive the encouragement (although this is certainly how many teachers institute their own successors). Much rather and by contrast, for Heidegger, what is incumbent on the teacher as teacher is letting learn. That means the teacher has to free the learner for his or her ownmost possibilities of and in being, including one's ownmost projects, concerns, challenges, and limitations. What is here at stake is Being as such.

Just as "the sign stays without interpretation," as Heidegger writes just before he turns to reflect on Hölderlin's Mnemosyne, the human being himself (or herself and this should always be said when we are speaking of Heidegger's or of Hölderlin's human being) is a sign, an indication pointing toward what is already withdrawn, revealed, and obscured, in eclipse. "We," he repeats this, "are a sign that is not read" (Heidegger 1976, p. 18). 
"We are trying to learn thinking" (Heidegger 1976, p. 16), so Heidegger teaches. What is Called Thinking? is a class, specifically: a written set of lectures for a class, and, exactly par for the course, he begins Lecture I of Part Two by reprising his reflection on the question: "What is it to which we give the name thinking?" (Heidegger 1976, p. 113). In the case of science, the investigation seeks to frame the query in a characteristic way, specific to the regional specificity of the science in question, and Heidegger also speaks of this more generally in terms of the age of "world picture." [I am of course referring to Heidegger's essay of the same name, but it is also part of his reflections in Being and Time: "Scientific research accomplishes, roughly and naively, the demarcation and initial fixing of the areas of subject-matter. The basic structures of any such area have already been worked out after a fashion in our pre-scientific ways of experiencing and interpreting that domain of Being in which the area of subject-matter is itself confined" [BT 1:3, 29/9)]. The scientist is interested in a certain representation of the world, and, as Heidegger also points out, the modern, technologically advanced scientist is interested rather less in attaining a theoretical understanding of a specific subject field than in being able to challenge forth nature productively in a specific, experimental, instrumentally calculable way. In part, this is all about the kind of query specific to science which, as Immanuel Kant had already pointed out in his own phenomenological reflection on the method of scientific understanding, follows a very specific questioning tack: by setting specific questions that nature is compelled to answer, instrumentally articulated. This is the experimental project of science, not an objective or neutral undertaking and often quite violent, sometimes, in the case of animal research, a very bloody, fatal matter of interrogative compulsion and torture. But by this kind of questioning, one finds, this is the specialized nature of modern science, just and only the answers one wishes.

Here, a phenomenological hermeneutics is invaluable as one can recognize that the kind of inquiry thereby scientifically deployed is exactly non-neutral, utterly subjective: one challenges forth toward quite specific ends not only of explanation but for the sake of technologizable prediction and, ultimately, for the sake of calculatively specific and indeed manufacturable control. What one has thereby is a techno-scientific picture of the world just to the extent that the means, the how, and the whereby and the ways of this interrogation will always be part of the scientific image presented. This eliminates the innocent idea of simply going up to nature, as it were, and figuratively, in the case of science, asking neutral or objective questions. For Heidegger by contrast, to return to the question of questioning, we note the relevance of what he calls, at the conclusion of his Question Concerning Technology, "the piety of thought" (Heidegger 1977, p. 35).

We only can ask after the means of our interrogation in the case of science (and in the case of the technology that we use to advance science), if we mean to question in such a way that we call our own presuppositions into question. In other words, we take ourselves to know in the case of modern, i.e., scientific, technology that we know what technology is (an instrument or a tool, a human undertaking or preoccupation); our presumption is that technology in its essence is already available to us in advance of any questioning after it. Here, we may now recall, this conviction stymies inquiry, getting in the way of any kind of questioning, superficial or genuine/authentic: why ask where we already know? In the case of technology, the problem is and remains that we seek to control technology. But where we do not see the problem, where we already know what technology is (it's a tool, it's a means: it's neutral, it's fundamentally human), control remains elusive. Heidegger later suggests in his lecture celebrating the local Messkirch composer, Conradin Kreutzer and published as Gelassenheit, what he had already pointed out in the Question Concerning Technology, namely, it is enough, if it is also hard enough, to reflect on what is needed to gain a "free relation" to technology as part of any philosophical inquiry that would ask after the nature of the essence of technology as of anything in particular.

A determination is already at work when we put the object of inquiry into question in a specific 
way, for a specific purpose, and in terms of a given disciplinary project or undertaking. We ask philosophical questions as we ask scientific questions, economic questions, political questions, religious questions, and spiritual questions, and we also ask idle questions and in no case are these questions themselves unspecified even in their non-specificity but require further reflection or thinking. As Heidegger says in The Question Concerning Technology, questioning is anything but nondirective: questioning is utterly intentional. Questioning is the phenomenological epoché articulated in a sentence: "questioning builds a way” (Heidegger 1977, p. 3).

Acknowledgments The author is grateful to Miles Groth for his valuable questions and for sharing his own email correspondence with me. The author also wishes to call attention to Valerie Allen and Aris Axiotis for their creative and (in the words of one commentator who supposes the text to have been Heidegger's own) "unusually accessible" vision of what Allen/Axiotis speculate that Heidegger would have said, had he said it, on the theme of what they (rather than Heidegger which may account for its accessibility) name the "Art of Teaching." Allen/Axiotis 2002. Cf., by contrast, Heidegger 2000, 376 and perhaps also 1998.

\section{References}

Allen, V., \& Axiotis, A.D. (2002). Heidegger on the art of teaching. In M. Peters \& V. Allen (Eds.), Heidegger, education and modernity (pp. 27-45). Lanham: Rowman and Littlefield.

Babich, B. (1993). A musical retrieve of Heidegger, Nietzsche, and technology: Cadence, concinnity, and playing brass. Man and World, 26, 239-260.

Babich, B. (2013). Nietzsche's Zarathustra and Parodic Style: On Lucian's Hyperanthropos and Nietzsche's Übermensch. Diogenes, 58(4), 58-74.

Babich, B. (2014). Nietzsche's Antichrist: The birth of modern science out of the spirit of religion. In M. Enders \& H. Zaborowski (Eds.), Jahrbuch für Religionsphilosophie (pp. 134-154). Freiburg im Briesgau: Alber.

Babich, B. (2015a). Heidegger's Jews: Inclusion/Exclusion and Heidegger's Anti-Semitism. Journal of the British Society for Phenomenology, 47(2), 133-156.

Babich, B. (2015b). Heidegger's black notebooks: The Nachlass and its Wirkungsgeschichte. In I. Farin \& J. Malpas (Eds.), Heidegger's black notebooks (pp. 59-86). Cambridge, MA: MIT Press.

Babich, B. (2015c). Heidegger on technology and Gelassenheit: wabi-sabi and the art of Verfallenheit. AI \& SOCIETY. Journal of Knowledge, Culture and Communication, 1-10.
Babich, B. (2015d). Un politique brisé. Le souci d'autrui, l'humanisme, et les juifs chez Heidegger. Paris: L'Harmattan.

Babich, B. (2016). Getting to Hogwarts: Michael Oakeshott, Ivan Illich, and J.K. Rowling on 'School'. In D. Bakhurst \& P. Fairfield (Eds.), Education and conversation: Exploring Oakeshott's legacy. London: Bloomsbury.

Brook, A. (2009). The potentiality of authenticity in becoming a teacher. In G. Dall'Alba (Ed.), Exploring education through phenomenology (pp. 53-65). Oxford: Wiley Blackwell.

Ehrmantraut, M. (2010). Heidegger's philosophic pedagogy. London: Continuum.

Fink, E. (1970). Metaphysik der Erziehung im Weltverständnis von Plato und Aristoteles. Frankfurt am Main: Klostermann.

Fink, E. (1979). Nietzsches philosophie. Stuttgart: Kohlhammer.

Gadamer, H.-G. (1989). Back from Syracuse. Critical Inquiry, 15(2), 427-430.

Gallagher, S. (1992). Hermeneutics and education. Albany: SUNY Press.

Gordon, H. (1998). Heidegger on poetry and thinking: Some educational implications. In Paideia: Twentieth world congress of philosophy. Boston Online.

Heidegger, M. (1933). Die Selbstbehauptung der deutschen Universität Rede, gehalten bei der feierlichen Übernahme des Rektorats der Universität Freiburg i Br. am 27. 5, 1933. Breslau: Korn Verlag.

Heidegger, M. (1976). What is called thinking? (trans: Glenn Gray, J.). New York: Harper.

Heidegger, M. (1977). The question concerning technology (trans: Lovitt, W.). New York: Harper \& Row.

Heidegger, M. (1985) The self-assertion of the German university and the rectorate 1933/34: Facts and thoughts. Review of metaphysics 38(3) 467-480 and 481.

Heidegger, M. (1998) Traditional language and technological language. Journal of philosophical research 23, 129-145. A translation of Überlieferte Sprache und Technische Sprache (1962). St Gallen: Erker.

Heidegger, M. (2000) Gesamtausgabe 1. Abteilung: Veröffentlichte Schriften: 1910-1976. Band 16. Reden und andere Zeugnisse eines Lebensweges. Freiburg i. B.: Vittorio Klostermann.

Hodge, S. (2015) Martin Heidegger: Challenge to dducation. Frankfurt am Main: Springer.

Malpas, J., \& Farin, I. (Eds.). (2015). Martin Heidegger's black notebooks. Cambridge, MA: MIT Press.

Mayer, A. (1960). Heideggers Beitrag zur Pädagogik. Zeitschrift der Pädagogik, 6, 138-148.

Meyer-Drawe, K. (1988). Aneignung - Ablehnung Anregung. Pädagogische Orientierungen an Heidegger. In A. Gethmann-Siefert \& O. Pöggeler (Eds.), Heidegger und die praktische Philosophie (pp. 231-250). Frankfurt am Main: Suhrkamp.

Meyer-Wolters, H. (1992). Koexistence und Freiheit. Eugen Finks Anthropologie und Bildungstheorie. Würzburg: Königshausen und Neumann. 
Nießeler, A. (1995). Vom Ethos der Gelassenheit. Zu Heideggers Bedeutung für die Pädagogik. Würzburg: Königshausen \& Neumann.

Nye, A. (1990). Words of power. London: Routledge.

Peters, M. (2009). Foreword. In G. Dall'Alba (Ed.), Exploring education through phenomenology (pp. ix-xiv). Oxford: Wiley Blackwell.

Peters, M. A., \& Allen, V. (Eds.). (2002). Heidegger, education, and modernity. Lanham: Rowman \& Littlefield.

Rançiere, J. (1991). The ignorant schoolmaster: Five lessons in intellectual emancipation (trans: Ross, K.). Stanford: Stanford University Press.
Standish, P. (1997). Heidegger and the technology of further education. Journal of Philosophy of Education, 31(3), 439-459.

Thomson, I. (2004). Heidegger's perfectionist philosophy of education in Being and Time. Continental Philosophy Review, 34, 439-467.

Tubbs, N. (2004). Philosophy's Higher Education, Dordrecht: Kluwer.

Waddington, D. (2005). A field guide to Heidegger: Understanding the question concerning technology. Educational Philosophy and Theory, 37(4), 567-583. 